\title{
The Development Model of Modern Islamic Education in Indonesia (Study over the Modern Islamic Boarding School of Darussalam Gontor Ponorogo)
}

\author{
Muhammad Heriyudanta ${ }^{1}$, Lukman Hakim ${ }^{2}$ \\ Institut Agama Islam Negeri Ponorogo ${ }^{1,2}$ \\ \{yudanta10@gmail.com¹, lukmanachim19@gmail.com²\}
}

\begin{abstract}
This paper intends to research and see how the development of modern Islamic education in the modern Islamic boarding school Darussalam Gontor, Ponorogo, East Java. In this study, it was found that the modernization breakthroughs taken by the Darussalam Gontor modern pesantren were in two forms. First, in terms of institutional management and management, and the second in terms of curriculum modernization. Pesantren Gontor is managed by donating it to the people, with the aim that the pesantren can grow in a more advanced, more open manner, and not lack a cadre of successors. While the curriculum has been modernized in accordance with the needs of human nature itself at the same time according to the needs of the times. This is marked by the provision of subject matter that teaches $100 \%$ general science and $100 \%$ religious knowledge, special emphasis on aspects of foreign language acquisition, and facilitates comprehensive extracurricular activities such as in the fields of skills, sports and arts. Therefore, the modern Islamic education development model developed by the Darussalam Gontor modern Islamic boarding school deserves to be a pilot project in the development of Islamic education in the contemporary era.
\end{abstract}

Keywords: Pengembangan; Pesantren; Gontor

\section{Introduction}

Indonesia can be said one of the countries that has extraordinary wealth. This can be seen from the country's resources, both its natural resources and its abundant human resources. Unfortunately, however, the abundance of natural resources and human resources in Indonesia has not been fully utilized. The inadequacy of our natural resource management, for example, can be seen from how Freeport company was managed. The proceeds of the Freeport gold mine, which should had been enjoyed by the Indonesian population, had been crushed and exploited on a large scale by a mining company from the United States. Meanwhile, we, as land owners, have only been given $1 \%$ of such a huge yield over the years. [1]

The evidence that our human resource has not been maximized can be seen from the position of Indonesia's human resources achievements in the global werea. Besides that, we can also saw how our children and even adults behave. In terms of achievements in various aspects, for example, Indonesia always occupied a middle to lower position in the 
international area. Even if there was a few that stood out, usually there was no special attention in their development. Meanwhile, in the context of ethical matters, we were often amazed. Why not, the strange behavior of our children was reported in various print and electronic media every day. For example, the case of student such as "bullying", student fights, female students who got pregnant outside of marriage and gave birth in the toilet, students skip school and get drunk, even now there was a case of a student who want to kill his teacher. At the higher education level, it was not much different. Students who were predicted to be able to carry out their duties as agents of change and social control were in fact the same. The academic culture of students in the past, as if it was no longer seen in campus corners and boarding houses. In contrast, malls, coffee shops, cafes, and strategic hangouts were always packed with students of the nation's next generation. Students in this era did not live the truth of Pancasila values if they were applied in their daily life, they will form a great nation generation.[2]

No less worrying, our citizens who happened to occupy positions in the central and regional governments also seem to continue to set some bad examples. Those who sit in the government in the executive, legislative, and even judicial realms, do not cease to carry out actions that we called massive acts of corruption, collusion and nepotism.[3] Worse, these corrupt behaviors have spread, mushroomed, and infiltrated the joints of our government from various levels and became heartbreaking chats in public spaces. According to researchers, the quality of human resources was mediocre and the management of natural resources was not maximal. Therefore, it was not an exaggeration to continue serious discussions about education world in order to find the right education system formula for this country done continously.

Almost as a general agreement, education was still used today to increase the living standard of people in all fields, as well as inherit moral and cultural values so that it occupied a strategic and central position in the midst of people's living.[4] For this reason, it was not surprising that from it an extreme thesis was born which said that, advancing or retreating a state civilization was determined by how education was built in it.

In the Indonesian context, islamic education as a sub-system of national education must participate dynamically and proactively in realizing a more established social order. His presence was expected to be able to make a significant contribution and bring a fresh air of changing for the improvement of people living in this country, both intellectually, emotionally, spiritually and include skills.[5] In fact, Islamic education was not just a medium that have functions to take care the human personality so that it has a good personality and was free from the negative impacts of globalization. But further than that, what was most urgent about islamic education was how the moral values that have been internalized by islamic education were able to free mankind from the shackles and crush of the economy, ignorance, as well as the backwardness of civilization.[5]

In Indonesia, islamic education was born before Indonesia was born into a country.[6] However, until now islamic education was still in a problematic position and has conditions that were (in general) still relatively apprehensive. According to Azyumardi Azra, when this country faced the challenges of the times and various complex problems that were tangled and difficult to decipher, islamic education has not been able to play its role.[7] Not only Azra, Tilaar as an Indonesian education expert also agrees with Azra's view.[8]

In Sutrisno's view, the condition of Islamic education as stated above was due to the fact that Islamic education itself has not been able to free itself from some of the shackles of a prolonged crisis.[9] The crises of Islamic education, among others; conceptual crisis, institutional crisis, orientational crisis, and methodological crisis.[9] These crisis in turn cause 
Islamic education to be underestimated by the society.[10] Especially if it was related to the global framework or what was called the information era and industrialization.[11] For these reasons, it was not an exaggeration that the development of Islamic education became very urgent, even a necessity. The portrait of Islamic education as described above must be used as a main reference in order to realize a higher quality, modern-based Islamic education order without leaving previously established concepts but the need for innovation and modification.

Starting from the phenomenon of the implementation of Indonesian Islamic education that has been described above, it was important to conduct research at the Daarussalam Gontor pesantren, Ponorogo,East Java with two important considerations. First, Modern Islamic Boarding School Daarussalam Gontor Ponorogo was seen by the wider community as a boarding school that has succeeded in transforming and modernizing Islamic education so that it was able to produce complete human beings, namely scholars-intellectuals and intellectualsscholars who have a big role and influence in Indonesia. Second, the Trimurti and Gontor caregivers were also known to the public to have progressive views and have an inclusive mindset (open minded), and have good attitudes and can be good role models.

\section{The Development Model of Modern Islamic Education in Modern Islamic Boarding School Darussalam Gontor, Ponorogo, East Java}

The education model, authority, and familiarity of the pesantren were usually very dependent and identical to the leader (Kyai). In fact, the success and failure of pesantren was largely determined by the expertise of the leadership and carers in managing the pesantren. Therefore, it was not an exaggeration to think that certain pesantren was a personal interprwase of the leader (Kyai). In the context of the Modern Islamic Boarding School of Darussalam Gontor, we know the founder and guardian, called K.H. Achmad Sahal, K.H. Zainuddin Fananie, and K.H. Imam Zarkasyi who became known as the "trimurti" of the Gontor Islamic Boarding School. The three persons were three brothers who were classified as typical leader who have a modernist view.

Trimurti's modernist thoughts actually emerged from his experience and reflection in seeing the reality of Islamic education in Indonesia and the world. In the context of Indonesia, Trimurti views that the system and management of Islamic education in Indonesia was still held in a static-conservative manner and it appears that there has been no significant transformation effort for the progress of Islamic education itself. Meanwhile, in other countries there were several Islamic educational institutions that were quite inspiring. Therefore, they want to carry out renewal of Islamic education, through the pesantren which they lead themselves.

\subsection{The Management of Institution and Organization}

In the context of institutional management, many pesantren in Indonesia were usually managed independently or centrally by the leader (Kyai) and their families. If we examine further, in fact one of the reasons for the dissolution of these pesantren in Indonesia was the absence of competent future generations in continuing the relay of leadership of the pesantren. For that reason, Islamic Boarding School of Gontor then responded by making a breakthrough by donating the management of institution and organization of the pesantren to the community. From there, Islamic Boarding School of Gontor no longer belongs to the personal "Kyai" caretaker and his family, but belongs to the Muslims in general. In this way, the 
Muslims can freely contribute and simultaneously feel responsible for the triumph of the Islamic Boarding School of Gontor.[12]

Apart from the reasons for concern that there will be difficulty in regenerating leaders, there were actually other reasons underlying the Islamic Boarding School of Gontor to the community. It was called, waqf was a form of worship, and the founders of Islamic Boarding School of Gontor were also inspired by the management of Al-Azhar Cairo, Egypt, which was known to be able to be managed properly as endowments and producing. So that until now, Al-Azhar can provide educational scholarships for students around the world. Another reason, it was because he wants to manifest a sincere spirit in a pure manner, sacrificing personal interests in order to achieve the public interest.

In order to advance and develop Modern Islamic Boarding School of Darussalam Gontor, then formulated a work program for the Islamic boarding school called "Panca Jangka" which serves as a direction and guidelines for achieving the progress of the Modern Islamic boarding school as desired. The five terms conswast of education and teaching. Regeneration, building, chizanatullah, and welfwere of Modern Islamic Boarding School families.

\subsection{The Education Curriculum of Modern Islamic Boarding School Gontor}

One of the striking differences between the pesantren in Gontor and other pesantren was in terms of the curriculum. Regarding the curriculum, Gontor choose to design its own curriculum and named it the KMI curriculum (Kulliyatul Mualimin Al-Waslamiyah). In carrying out its programs and activities, the KMI director was asswasted by eight KMI functionaries whose membership consists of senior teachers. The founder of the Gontor pesantren has the view that the curriculum was not only the composition of the subjects taught, but also the curriculum was everything that was contained in educational programs, both express and implied. [13] Therefore, the KMI curriculum which was used for classical learning in Islamic boarding does not stand alone, but was also integrated with learning in the dormitory, all of which work together in producing superior humans who become scholars', pious, solih, and useful people.[13]

\subsection{The Educational Aims of Modern Islamic Boarding School Gontor}

According to Imam Zarkasyi, one of the shortcomings of Islamic boarding schools in the past was that there were no educational aims outlined in educational programs and plans. So that the pesantren seems to be running according to the directions and orders of the "Kyai". Seeing this, then the leadership of the Gontor pesantren formulated the educational aims of their pesantren. Modern Islamic Boarding School Gontor has educational aims that were not much different from other educational institutions. The aims were more or less to galvanize and build a person who has a strong faith, excellent devotion and has good character who was willing and able to serve the people with full sincerity and participate actively in efforts to empower the community.

\subsection{The Subject Matter of Pesantren in Modern Islamic Boarding School Gontor}

The Trimurti of Gontor rejected the dichotomized view of knowledge that once became part of the islamic civilitazion history. He agreed with the islamic reformers who held the view that all knowledge was sourced from Allah SWT. So that all knowledge was not separated between general knowledge and religion. Even the clumps of knowledge that were 
said to be non-religious sciences were actually part of religious knowledge. Starting from such a scientific paradigm, pesantren in Gontor does not dichotomize knowledge and thaught $100 \%$ general science and $100 \%$ religious knowledge.[14]

The subject matter be taught at the Gontor pesantren was almost the same as the lesson in islamic school in general. In Gontor, knowledge was taught so useful for the life in the world and afterlife (akhirat), including the knowledge of aqidah, tafsir, hadith, ushul fiqih, fiqh, morality, islamic cultural history, physics, chemistry, mathematics, biology, economics, history, geography, sociology, arts, culture, and so on. It's just that religious knowledge materials such as Arabic, Balaghah, Mantiq subject, Aqidah, Fiqih, Tajweed and so on, used books that compiled by the pesantren itself. This policy was taken so that students could more easily understand the substance of these knowledge, because indeed the books taught were the substance or essence in general of the subject were being taught. However, there was another striking difference between the Gontor pesantren and other pesantren. The difference that can be seen directly that was mastering of foreign language and providing quite compliting extracurricular there.[14]

The Trimurti of Gontor pesantren really understood that when Gontor students only receive education that touched cognitive and psychomotor aspects only, then the expected whole human will not be born. Therefore, in this pesantren also emphasized mental/spiritual/affective education. In order to educate the soul and spirit of the students, the Gontor pesantren had basic values of struggle and dedication that underlie all pesantren life, both while in the pesantren and when it was already involved in society. These five values which were called "panca jiwa" were truly internalized into the souls of the young students and were highly emphasized by the leader/islamic teacher there. The five values were the spirit of sincerity, the spirit of simplicity, the soul of independence, the soul of ukhuwwah islamiyah, and the spirit of freedom..

\subsection{Schedule of Activities, Methods, Media, and Learning Evaluation of the Modern Islamic Boarding School of Darussalam Gontor}

The activities of the students at Modern Islamic Boarding School of Darussalam Gontor can be classified into four activities.[15] We called, daily, weekly, semester and yearly activities. In relation to methods, media, and evaluation of learning, in general, the learning components of the pesantren are carried out traditionally. Usually there were several types of learning methods used to study books written by ulama salaf, that were, sorogan, bandongan, wetonan, and halaqoh learning systems. However, some of the components of the pesantren teaching system had been modernized by the Gontor pesantren. The reason was because according to the founder of the Gontor pesantren, such traditional methods can only reach intelligent students, while less intelligent students found it difficult to understand the contents of the book being studied.

Kyai in Gontor then used a method called the classical method, as was already applied in public schools and madrasah at that time. As we already know, this classical learning system actually adopted the Dutch education system. In learning, this system uses blackboard, chalk, tables, chairs, classrooms, books, and so on. Every six months an evaluation was held to measure the learning and educational outcomes that have been passed. The learning period lasts for six years, starting from grade 1 to grade 6 . This first class was at the level of grade 1 at madrasah tsanawiyah and grade six was at grade 3 at madrasah aliyah. The students studied in classes and are accompanied by their respective teachers, both teachers and students using pantalon and ties. This was where one of the origins of the Gontor pesantren was stigmatized 
as a modern pesantren.[13] The expectations of the pesantren leadership, by using current learning methods and media, the subject matter will be easier to understand, and educational goals can be achieved properly.

\subsection{Analysis of Institutional Management Relevance and Organization of Modern Islamic Boarding School of Daarussalam Gontor, Ponorogo}

As explained above, the management of the Gontor pesantren was carried out by donating the management of the boarding schools and organizations to the people. This major breakthrough was taken by the Gontor Islamic boarding school, of course not without good reasons. At least there were several reasons so that the Gontor pesantren took this breakthrough. First, there were many cases regarding the closure or dissolution of Islamic boarding schools because there were no cadres to continue the struggle of the founders and their caretakers. Second, the founder of the Gontor pesantren was well aware that waqf was a form of worship. Third, the Gontor Islamic boarding school was inspired by the management of Al-Azhar Cairo in Egypt, which was known to be able to be managed well and produce endowments. So that until now, Al-Azhar had been able to provide educational scholarships for students around the world. Fourth, the Gontor pesantren want to create a sincere spirit of sincerity, sacrificing personal interests in order to achieve the public interest.

According to researchers, the attitude of Trimurti, the founder of the Gontor Islamic boarding school, who donated the pesantren that had been pioneered painstakingly by him and was also an Islamic boarding school inherited from his ancestors, can be said to be an attitude that was very noble and truly big-spirited. Because, by donating the Gontor pesantren to the people, it mean that the Trimurti of Gontor pesantren and their families do not have free ownership rights and management rights over the Gontor pesantren. It is not even possible to manage the pesantren freely, let alone take material benefits from the pesantren at will. In the midst of human nature who were created as servants who really love worldly assets, perhaps not all of us were capable of taking such noble actions. In general, when people own assets, they will usually be managed independently and most of the proceeds will be enjoyed alone with their families. And that's not wrong, but it's okay. But at this point, Trimurti of Gontor pesantren took a different attitude, namely by donating his pesantren to the people. Some of the reasons underlying the donation of the pesantren to the community made perfect sense. Namely, with the donation of pesantren, the hopes and goals of pesantren can develop more rapidly, be more advanced, be more useful, and avoid stagnation, or even dissolution of the pesantren. The simple logic was, when the pesantren belongs to the people, the pesantren will not run out of successor cadres and will not run out of their minds in developing the pesantren to a better direction. All Muslims feel they have and were responsible for the continuity of the role and existence of the pesantren.

\subsection{Relevance Analysis of Educational Curriculum in Modern Islamic Boarding School Darussalam Gontor}

Regarding the curriculum used as a guideline for the Gontor pesantren in carrying out its daily education, it had been explained above that the Modern Islamic Boarding School Darussalam Gontor carries out the development of modern Islamic education. In its development, Gontor made a breakthrough that was slightly different from other pesantren. The distinction of developing Gontor boarding school education with others lies in its curriculum, emphasis on mastery of foreign languages, and its extracurricular activities were 
quite complete and adequate. From the long explanation above, it was concluded that Gontor Islamic boarding school education had clear objectives and achieves success in two dimensions (world-afterlife), integrative-interconnective subject matter, modern learning methods and media, emphasizing foreign language skills. Meanwhile, to support its educational goals, Gontor had a complete extracurricular activity, from arts, culture, sports, skills and so on..

If we analyze by using educational theories,[16] the modern Islamic education development model shown by the Gontor pesantren was very relevant and worthy of being a pilot project or modeling for other pesantren that still maintain their traditionalism ideology. This was in line with Azyumardi Azra's view, which stated that maintaining the traditional education model only prolongs the backwardness and desolation of the Muslims from the rest.[17]

\section{Conclusion}

Based on the explanation and data analysis above, it can be concluded that the management of institutional and organizational management of the Modern Islamic Boarding School Gontor was carried out by donating them to the community. According to researchers, the attitude of Trimurti, the founder of the Gontor Islamic boarding school, who donated the pesantren that had been pioneered painstakingly by him and was also an Islamic boarding school inherited from his ancestors, can be said to be an attitude that was very noble and truly big-spirited. Apart from that, his breakthrough was also very visionary, because the purpose of this pesantren was to support the pesantren to develop more rapidly, be more advanced, be more useful, and avoid stagnation or even dissolution of the pesantren. The Gontor curriculum, which taught $100 \%$ general knowledge and $100 \%$ religious knowledge, which puts special emphasis on mastery of foreign languages, and provides extracurriculars that were quite complete and adequate, according to researchers, it was very suitable to be used as a pilot project or modeling for other pesantren that still maintain traditional ideology.

\section{References}

[1] Hakim, Lukman: Penguatan Pendidikan Pancasila Sebagai Jatidiri, Refleksi, Dan Tantangan Dalam Membatasi Paham Radikalisme Mahasiswa Di Perguruan Tinggi Islam.Muslim Heritage Vol 4, No.2 (2019).

[2] Hakim, Lukman, and Ekapti, Rahmi Faradisya: "Penguatan Pendidikan Pancasila Sebagai Jatidiri, Refleksi, dan Tantangan dalam Membatasi Paham Radikalisme Mahasiswa di Perguruan Tinggi Islam Ponorogo.” Muslim Heritage 4, no. 2 (2019).

[3] Kompas Nasional: Kasus DPRD Kota Malang, Korupsi Massal Yang Mengkhawatirkan', Http//Nasional.Kompas.Com/Read/2018/09/04/08512451/KasusDprd-Kota-Malang-Korupsi-Massal-Yang-Mengkhawatirkan. Diunduh Pada 24 September 2018.," n.d.

[4] Furchan, Arief: Arief Furchan, Transformasi Pendidikan Islam Di Indonesia (Yogyakarta: Gama Media. 2004), Hlm. 14. Yogyakarta: Gama Media, 2004.

[5] Syafi'I Ma'arif, Ahmad: “'Rekonsiliasi Epistemologi Dalam Pendidikan Islam: Sebuah Keniscayaan' Dalam Moh. Shofan (Ed) 'Pendidikan Berparadigma Profetik: Upaya 
Konstruksi Membongkar Dikotomi Sistem Pendidikan Islam (Yogyakarta: IRCiSoD. 2004), Hlm. 5," n.d.

[6] Abdul Karim, M: Islam Nusantara. Yogyakarta: Pustaka Book Publisher, 2007.

[7] Azra, Azyumardi: 'Kata Pengantar' Dalam, Armai Arief, Reformulasi Pendidikan Islam (Jakarta: CRSD Press. 2005), Hlm. Vi," n.d.

[8] Bakar dan Surohim, U. A.: Fungsi Ganda Lembaga Pendidikan Islam: Respon Kreatif Terhadap Undang-Undang SISDIKNAS (Yogyakarta: Safiria Insani Press. 2005), Hlm., n.d.

[9] Sutrisno: "Pengembangan Kreatifitas Dalam Pendidikan Islam Kontemporer", Dalam Tim Penulis, Pendidikan Islam Dalam Konsepsi Dan Realitas.Yogyakarta: Lembaga Penelitian UIN SUKA. 2006, Hlm. 57, n.d.

[10] Tolkhah, Imam, and Ahmad Barizi: Membuka Jendela Pendidikan: Mengurai Akar Tradisi Dan Integrasi Keilmuan Pendidikan Islam (Jakarta: PT Radja Grafindo Persada. 2004), Hlm. 10-11, n.d.

[11] A. Malik, Fadjar.: Visi Pembaruan Pendidikan Islam (Jakarta: LP3NI. 1998), Hlm. 32, n.d.

[12] Abudinnata: Tokoh-Tokoh Pembaharuan Pendidikan Islam Di Indonesia (Jakarta: PT RajaGrafindo Persada, 2005), Hlm,. 213-214, n.d.

[13] Tim Penyusun: K.H. Imam Zarkasyi Dan Gontor Merintis Pesantren Modern (Ponorogo: Gontor Press, 1996), Hlm. 51, n.d.

[14] Yusuf, Ust. Barca: at Pondok Pesantren Modern Gontor, July 6, 2020.

[15] Hardoyo, Hafid: "Kurikulum Tersembunyi Pondok Modern Darussalam Gontor." AtTa'dib 4, no. 2 (2009).

[16] Tafsir, Ahmad: Ilmu Pendidikan Dalam Perspektif Islam. Remaja Rosdakarya, 1992.

[17] Heriyudanta, Muhammad: "Modernisasi Pendidikan Pesantren Perspektif Azyumardi Azra." MUDARRISA: Jurnal Kajian Pendidikan Islam 8, no. 1 (2016): 145-172. 